\section{A Proposal for a Principal Based Approach to Conservation Project Preparation Process of Architectural Heritage}

Mustafa Önge1, ORCID: 0000-0003-2886-5359

\section{Keywords}

architectural heritage, heritage conservation, cultural heritage, restoration

\section{Abstract}

The project phases for the protection of the architectural heritage comprise different stages of development and have different methods and procedures than that of the new buildings'. The project phase for the protection of the architectural heritage begin with the recognition of all aspects of the structure and the acquisition of information about its past during the detection and research stage, and continue with the investigation of its original state and relationship with similar structures. It ends with the submission of intervention proposals to stop the deterioration mechanisms of the structure and the final project proposal that may include a new function which could be given considering the structure's physical status. In this study, principles are proposed to be taken for the project preparation process to be carried on in a healthy manner. These principles are proposed considering the legislation of heritage conservation in Turkey and international and national texts on heritage conservation. The principles are as follows: Permanent priority of conservation, case by case approach, scientific approach, multidisciplinary and open-minded approach, interaction with legislation, applicability, continuity, respect, compliance with ethics and responsibility of the architect.

\section{Article Information}

Received: 27.11.2019

Accepted: 10.01 .2020

Available Online: 28.01 .2020

Article Info: Research Article
1. Çankaya University, Department of Architecture, Ankara, onge@cankaya.edu.tr 


\section{Türkiye'de Mimari Mirasın Korunmasında \\ Proje Sürecine İlkesel Bazda Bir Yaklaşım \\ Denemesi}

Mustafa Önge ${ }^{1}$, ORCID: 0000-0003-2886-5359

$\ddot{O} z$

Mimari mirasın korunmasına yönelik proje süreçleri, uygulamaya yönelik farklı gelişim aşamalarını içeren ve yeni yapı üretim süreçlerinden farklı işleyişe sahip süreçlerdir. Mimari mirasın korunmasına yönelik proje süreçleri, tespit ve araştırma aşamasında yapının tüm yönleriyle tanınması ve geçmişine yönelik bilgi edinilmesi ile başlar, benzeri türden yapılar ile ilişkisinin ve özgün halinin araştırılması ile devam eder. Yapının bozulma mekanizmalarının durdurulmasına ilişkin müdahalelerin ve yapının fiziksel durumuna göre yeni bir işlevi de içerebilen final proje önerisinin sunulması ile sona erer. Bu çalışmada, projelendirme süreçlerinin sağlıklı bir biçimde yürüyebilmesi ve uygulamada nitelikli sonuçlar alınabilmesi için koruma konusundaki uluslararası ve ulusal metinlerle Türkiye'deki koruma mevzuatı ve bağlı koşulları dikkate alınarak ilkeler önerilmiştir. Bu ilkeler; korumanın daimi önceliği, vaka bazında yaklaşım, bilimsel yaklaşım, multidisipliner ve katılımcılığa açık yaklaşım, mevzuatla etkileşim, uygulanabilirlik, süreklilik, sayg1, etiğe uygunluk ve mimarın sorumluluğu olarak belirlenmiştir.

\section{Anahtar Sözcükler}

mimari miras, kültür mirasının korunmas1, kültür miras1, restorasyon

Makale Bilgileri

Alındı: 27.11.2019

Kabul edildi: 10.01 .2020

Erişilebilir: 28.01 .2020

Makale Bilgisi: Araştırma Makalesi

1. Çankaya Üniversitesi, Mimarlık Bölümü, Ankara, onge@cankaya.edu.tr 


\section{GİRIŞ (INTRODUCTION)}

Toplumlar için farklı değerler taşıyan somut ve somut olmayan kültür mirası, toplumların kimliğinin korunmasına bir katkı olarak gelecek nesillerine intikal ettirilmeye çalışılmaktadır. Karmaşık kuramsal ve teknik tartışmaları da içeren bu süreç içinde, kültür mirasının korunmasına yönelik tüm girişimler, belli bir program ve sistem içinde, uluslararası kabul görmüş kurallar ve toplumların kendi kültür miraslarını korumaya yönelik endişeleri gözetilerek yapılır. Bu girişimler, demokratik ülkelerde devlet tarafindan desteklenir ve yürütülür. Ülkemizde de bu kapsamda somut ve somut olmayan kültür mirasının korunmasına yönelik çalışmalar yapılmaktadır.

Bu çalışmanın konusu olan mimari miras kavramı, kültür mirası kavramı içerisinde somut kültür mirası ana başlığı altında taşınmaz kültür mirası grubunda yer alır. Mimari mirasın korunmasında proje süreci ise, mimari mirasın fiziksel durumunun yapılmış olan tespitlerle ortaya konduğu ve onu sahip olduğu değerlerle birlikte korumaya ve gelecek nesillere intikal ettirmeye yönelik müdahalelerin önerildiği, sınırları net olmayan bir planlama aşamasıdır. Çalışma kapsamında ilk bölümde proje süreci hakkında ayrıntıll bilgi verilerek, süreç, çeşitli aşamaları, sebep sonuç ilişkileri ve sorunlarıyla ortaya konmaya çalışılmış, ikinci bölümde ise proje sürecinde uyulması önerilen ilkeler sunulmuştur.

Kültür mirası ile ilgili çalışmalarda uyulması gereken kurallar oluşturma isteği, şüphesiz yeni bir durum değildir. Koruma kavramının ortaya çıkışıla, ilk koruma kuramcılarının yordama ilişkin düşünceleriyle çağdaş olduğu söylenebilir. Bu çalışmadaki amaç yeni bir kuram ortaya koymak veya mevcut kurallara yenilerini eklemek değildir. Zira 19.yüzyıldan günümüze değin yapılan tartışmaların oluşturduğu zengin ve değerli birikim böyle bir çabayı büyük ölçüde gereksiz kılmaktadır. Öte yandan tüm dünyada geçerli yaklaşımların hatırlatılması ve Türkiye bağlamında çözülememiş sorunların çözümüne, ulusal ve uluslararası metinlerle uygulama süreçlerinin bağlantısını kurma yolunda katkıda bulunması amacıyla, belli bir hiyerarşi ve sistem kurgusu içinde, ilke önerileri ortaya konulmaya çalışılmıştır. Sunulan tüm ilke önerileri, güncel yaklaşımlarla uyumu ve kapsamı bağlamında genişletilmeye ve geliştirilmeye açı olup, yazarın, aldığı koruma eğitimi, değerlendirdiği ve çalıştığı projelerden edinimleri, akademik ortamlardaki kazanımları ve incelediği projelerden yaptığı çıkarımlara dayanmaktadır. Bu çalışmada amaçlanan, bir vakayı, müellifi, siyasal partiyi veya bir kurumu eleştirmek olmadığından proje süreci ile ilgili kısımlarda ve ilke önerilerinde sorunlar ile ilgili birebir örnekler verilmesinden kaçınılmıştır. 


\section{MİMARİ MİRASIN KORUNMASINDA PROJE SÜRECİ (PROJECT PREPARATION PROCESS IN ARCHITECTURAL HERITAGE CONSERVATION)}

Proje süreci temel olarak, Tespit ve Araştırma, Sentez ve Öneri aşamalarından oluşur. Bu aşamalar işleyiş anlamında hiyerarşik bir düzene sahip olup, farklı türde bilgi girdileriyle sürecin bir bütün halinde tutarlı ve sağlıklı işlemesini sağlarlar.

Sürecin ilk aşaması, Tespit ve Araştırma Aşaması'dır. Bu aşama, Rölöve, Analizler, Laboratuvar Analizleri, Tarihçe Çalışması, Araştırma Kazısı Rapor ve Çizimleri ve yapının fiziksel durumunu daha iyi anlamaya yönelik yapılmış diğer tespitler doğrultusunda ihtiyaç duyulan tüm bilgilerin toplandığı süreç olarak tanımlanabilir. Genel olarak yapıyı ve yakın çevresini pek çok açıdan tanımaya yöneliktir. İkinci aşama, Sentez aşamasıdır. Toplanan bilgilere yenilerinin eklenmesiyle yapının değeri, fiziksel durumu, özgün hali ve diğer nitelikleri hakkında fikir oluşturulduğu ve buna göre öncelikle yapının maruz kaldığı bozulma süreçlerini durduracak müdahalelerin kararlaştırıldığ1 süreçtir. Son aşama ise Öneri aşamasıdır. Bu aşama mimari mirasın, değerleri ile birlikte korunarak gelecek nesillere intikal ettirilmesine yönelik önerilerin sunulduğu, eğer uygun görülüyorsa işlev ve bu işlevin gereği müdahalelerin önerildiği süreci içerir.

Mimari mirasın korunmasında projelendirme sürecine başlamadan önce bazı ön hazırlıkların yapılması gerekir. Ülkemizdeki genel işleyiş, mimari mirasın öncelikle 2863 sayılı Kültür ve Tabiat Varlıkları Kanunu'nun 7.maddesine göre tescil edilmesi ve sonrasında, ilgili koruma bölge kurulu kararı doğrultusunda korunmasına yönelik projelerin hazırlanması biçiminde gelişir. Bu kapsamda yapılması gereken çalışmaların genel nitelikleri, Kültür Varlıklarını Koruma Yüksek Kurulu’nun 660 sayılı ilke kararı kapsamında açıklanmıştır. Proje süreci öncesindeki tescil aşaması konunun hukuki boyutunda özel bir öneme sahiptir. Tescil, söz konusu mimari mirasin ulusal envantere kayıt edilmesini ve 2863 sayılı kanun hükümleri kapsamına girmesini sağlar. Kanunun gereği olarak söz konusu mimari mirasın korunması ile ilişkilendirilebilecek her türlü kararı alma yetkisi ilgili koruma bölge kuruluna ait olur.

Proje süreci öncesindeki bir başka önemli husus ise korunması istenen mimari miras ile ilgili mülkiyet durumunun açıklığa kavuşturulmuş olmasıdır. Eski yapılar ve tesisler çoğu zaman konuyla ilgili devlet kurumunun mülkiyetinde bulunuyor olsa dahi bu durum her taşınmaz kültür mirası için geçerli değildir. Özellikle tarihi konut yapılarının pek çoğu özel mülkiyettedir. Anıtsal yapıların pek çoğu Vakıflar Genel Müdürlüğü mülkiyetinde olsa dahi, bazı hallerde, süregelen bir vakıf kurumunun parçaları olmaları nedeniyle miras yolu ile çoklu bir mülkiyet düzenine sahip olduğundan, mümkünse tüm mülkiyet sahiplerinden koruma projesinin hazırlatılması ve ilgili koruma bölge kuruluna sunulması sürecinde muvafakat alınması gerekmektedir. Proje ve uygulama süreçlerinde bu nedenle ve benzeri nedenlerle bir hukuki süreç başlatılması durumunda, hukukun üstünlüğ̈ ilkesi uyarınca mahkemenin alacağı kararın esas olacağı, bununla beraber, proje ve uygulama süreçlerinin mahkeme tarafindan durdurulabileceği ve bunun neticesinde yeni sorunlarla karşılaşılabileceği de unutulmamalıdır. 


\section{Tespit ve araştırma aşaması (Detection and research stage)}

Tespit ve araştırma aşaması, proje süreci içindeki en zor, bununla beraber en önemli aşamadır. $\mathrm{Bu}$ hususun müellif ve mal sahibi tarafindan kabul görmesi, uygulanacak her türlü işlem hususunda sabır ve anlayış gösterilmesi gerekir. Zira her koruma öyküsü ayrı bir vaka olup sadece problemlerin türü bakımından benzerlik gösterdiğinden yapılacak çalışmaların miktarı da örnekten örneğe değişecektir.

$\mathrm{Bu}$ süreç içerisinde, hazırlanan her türlü belgede, doğru, sistemli ve eksiksiz bilgi verilmelidir. Raporlar genelden özele doğru, referanslı, konu odaklı bir anlatım düzeni içinde hazırlanmalıdır. Çizimler ise mimari ifade teknikleri ile ilgili uluslararası kurallara uygun ve anlaşıllır olmalı, fotoğraflarla desteklenmelidir. En önemlisi, bu aşamada, yorumlara değil tespitlere yer verilmeli, yapıyı tehdit eden sorunların doğru teşhisi için öncelikli olarak sorunlara ilişkin tüm belirtilerin saptanıp, tüm sınamaların yapılıp değerlendirilmeye alınması gerekir. Buradaki yaklaşım biçimi doktorun hastaya yaklaşım biçimine benzetilebilir (Massari, 1977, s.5). Sorunların teşhisi konusunda acele edilmemesi, peşin hükümlü davranılmaması, bilimsel yaklaşımdan taviz verilmemesi çok önemlidir.

\section{Rölöve ve görsel belgeleme (Architectural survey and visual documentation)}

Rölöve ya da diğer adıyla "tıpkıçizim”, bu süreç içinde apayrı bir öneme sahiptir (Alsaç, 1992, s.66). Mimari mirasın yakın çevresi ile beraber ölçülerinin alınması ve sonrasında ölçekli çizimlerinin oluşturulmasıdır (Uluengin, 2002, s.21). Koruma projelerinin görsel kısmı ile ilgili en önemli aşamadır. Rölöve çizimlerinin, ölçekli çizimler olmasının ötesinde, yapıya ait toplanan her türlü bilginin üzerine işlenebildiği bir altlık oluşturması da beklenir. Bu niteliğiyle hasar ve bozulma analizi, taşıyıcı sistem analizi ve diğer analizlerin ifade edilmesi, onarımlara ait metraj ve keşiflerin doğru olarak çıkartılabilmesi için çok önemlidir. Dolayısıyla, mimari ifade olarak eksiksiz ve doğru çizilmiş olması, yapının onarımına ait alınan kararın tarihine göre güncel durumu yansıtıyor olması şarttır. Bu aşamada oluşabilecek hatalar ve ihmaller tüm proje ve uygulama süreçlerini olumsuz etkileyecektir.

Klasik yöntem, Fotogrametri ve Laser Tarama olmak üzere üç temel yöntemle hazırlanır. Bu yöntemlerin hepsi halen geçerli yöntemler olup, her birinin avantaj ve dezavantajları vardır (Tablo 1). Rölöve için yöntem seçimi genel olarak bir tercih ya da imkân sorunudur. Klasik rölöve için gereken ekipmanın temininin kolay olmasına ve rölöveyi alan kişi haricinde eğitimli personel gerektirmemesine rağmen, ölçüm ve çizim süreçleri zaman almakta, karmaşık formlu yap1 elemanlarının ölçümü ise yer yer temel geometri kurallarına bağlı çözümler üretilmesini gerektirmektedir. Eğitimciler ve rölöve konusunda kendini yetiştirmek isteyenler için klasik rölövenin kavram, malzeme, yöntem ve tekniğine ilişkin hususlarda doyurucu bilgi içeren Türkçe kaynaklar da mevcut olup, Bülent Uluengin'in (2002) eseri bu alana önemli bir katk1 olarak öne çıkmaktadır. Fotogrametri ve lazer tarama yöntemlerinde ise, arazide geçirilen süre çoğu zaman birkaç saati geçmese de hem ölçüm hem de çizim için nispeten pahalı ekipmana ihtiyaç duyulmakta, rölöve almak için bu ekipmana yönelik eğitim almış personelin varlığ1 zorunlu kılınmaktadır. Gelişen teknolojinin belgeleme konusunda sağladığı mutlak avantajlara ne ölçüde ihtiyaç duyulduğu da dikkate alınmalıdır. Örneğin, yoğun bitki örtüsü nedeniyle hava fotoğrafı alınamayan, klasik 
rölöve yöntemlerinin ise güçlükle uygulanabildiği vakalarda, bir lazer tarama türevi olan Lidar yöntemi kullanılarak vaziyet planı ölçümleri yapılabilmektedir (Lidar, 2019). Bina ve sokak ölçeğinde ise özellikle karmaşık formlu elemanların belgelenmesinde Lazer tarama yöntemi tartış1maz biçimde avantaj sağlamaktadır (Büyüksalih, 2002, s.56).

Tablo 1. Rölöve yöntemleri

\begin{tabular}{|c|c|c|}
\hline $\begin{array}{c}\text { Rölöve } \\
\text { Yöntemi }\end{array}$ & Avantajları & Dezavantajları \\
\hline $\begin{array}{l}\text { Klasik } \\
\text { Yöntem }\end{array}$ & $\begin{array}{l}\text { Basit ve nispeten ucuza temin } \\
\text { edilebilecek donanımla çalışılabilir. } \\
\text { Rölöve alacak ekip kısa bir eğitimle } \\
\text { hazırlanabilir. Yapıya dokunup uzun } \\
\text { süre gözlem yaparak yapıyı daha iyi } \\
\text { tanıma, not alma olanağı sağlar. Genel } \\
\text { olarak ekonomik olduğu söylenebilir. }\end{array}$ & $\begin{array}{l}\text { İki ölçücü ve bir yazıcıdan oluşan en az } \\
\text { üç kişilik bir ekip gerektirir. Hem } \\
\text { ölçümü hem de çizimi uzun zaman } \\
\text { alabilir, yapının yüksek kısımları gibi bazı } \\
\text { bölümleri ölçmek güçtür. Amorf } \\
\text { şekilleri, eğrilikleri ölçmek güçtür ve } \\
\text { nitelikli ekipman gerektirir. Ölçüm } \\
\text { hassasiyeti ile ilgili sorunlar her zaman } \\
\text { mevcuttur. }\end{array}$ \\
\hline $\begin{array}{l}\text { Fotogrametri } \\
\text { Yöntemi }\end{array}$ & $\begin{array}{l}\text { Ölçüm kısa sürer. Üç boyutlu } \\
\text { fotografik görüntü üzerinden iki } \\
\text { boyutlu çizim üretilir. Her türlü detay } \\
\text { ölçülü olarak çizime işlenebilir. }\end{array}$ & $\begin{array}{l}\text { Özel donanım ve eğitimli kullanıcı } \\
\text { gerektirir. Çizimlerin hazırlanması klasik } \\
\text { yöntemdeki kadar zaman alabilir. } \\
\text { Ölçümün ve çizimin hassasiyeti } \\
\text { kullanılan donanıma, kullanıcısına ve } \\
\text { fotoğrafın çekildiği ortama bağlıdır. }\end{array}$ \\
\hline $\begin{array}{l}\text { Laser Tarama } \\
\text { Yöntemi }\end{array}$ & $\begin{array}{l}\text { Ölçüm kısa sürer. Belirli noktalardan } \\
\text { üç boyutlu taramalar yapılarak } \\
\text { oluşturulan nokta bulutlarının alınan } \\
\text { görüntülerle çakışık halde bilgisayar } \\
\text { destekli tasarım ortamına } \\
\text { aktarılmasıyla önce model, sonra } \\
\text { çizim oluşturulur. Karmaşık formlu } \\
\text { elemanların belgelenmesinde mutlak } \\
\text { avantaj sağlar. }\end{array}$ & $\begin{array}{l}\text { Özel donanım ve eğitimli kullanıcı } \\
\text { gerektirir. Pahalı bir yöntemdir. Oluşan } \\
\text { çizim bir bilgi yığını halinde } \\
\text { bulunduğundan kategorize edilmesi ayırı } \\
\text { bir çalışma gerektirir. }\end{array}$ \\
\hline
\end{tabular}

Görsel belgeleme ise fotoğraf ve video çekimi ile yapılır. Bu süreçte genelden detaya ve her zaman belirli bir düzen içerisinde yapı kayıt altına alınır. Fotoğraf, genel gözlemlerin yanı sıra, malzeme, doku, şekil, boyut, şekil bozuklukları, sayılar, tefriş gibi konularda kroki yapmaksızın, daha çabuk ve hatasız bir perspektifle bilgi temin eder, alınması zor ölçülerin elde edilmesini sağlar (Uluengin, 
2002, s.42). Fotoğraflar, statik durumları kayıt altına almaya yararken, video kayıtları ise belgelenen mimari mirasın, eğer mevcutsa, hareketli ögeleri ile bu ögelerin işleyişini, detayların ait oldukları mekânlarla bağlantılarını, mekânların kendilerine komşu mekânlara akış ve bağlantılarını da anlatır. Çekilen fotoğraflar ve oluşturulan video kayıtları rölöve çizimlerindeki mekân kodları ve kardinal yönler gibi referanslarla uyumlu olarak, dijital veya basılı albümler halinde düzenlenir. Böylece projenin sonraki aşamalarında istenilen görsel kayda kolayca ulaşılabilesi mümkün hale gelir.

\section{Analizler (Analyses)}

"Analitik rölöve" adı da verilen analiz aşaması, basitçe mimari mirasa ilişkin edinilmiş bilgilerin farklı kategorilere ayrılıp sadeleştirilmiş rölöve çizimleri üzerinde gösterilerek sunulmasıdır (Kuban, 2000, s.145-146). Yapıdaki hasar ve malzeme sorunları, yapının malzemesinin türü, taşıyıcı sistem elemanlarının dağılımı ve yapının geçirmiş olduğu değişiklikleri veya yapıya farklı türden müdahaleleri gösteren izler, başlıca analiz başlıklarıdır. Yapının geçirmiş olduğu, açıkça görülen yapısal değişiklikler varsa bunlar da bir analiz başlı̆̆ altında ifade edilmelidir. Analiz hazırlamak, edinilen bilgilerin kategorize edildiği, farklı türden bilgilerin birbirleriyle ilişkilendirildiği bir bilgi yönetimi faaliyetidir. Analizlerde ortaya konan durum ve buna bağlı olarak tanımlanan problemler, müdahale kararlarına gerekçe oluşturur.

Son birkaç y1l içerisinde, lazer tarama tekniğinin popülarite kazanması ile eş zamanlı olan bir süreçte, tarama dosyaları ile birlikte hazırlanan ve "ortofoto" olarak bilinen görsellerin analiz çalışmaları yerine kullanılmasına yönelik bir eğilim gözlenmektedir. Bu görsellerin, farklı kategorilerde bilgileri birbirinden ayrıştırılmaksızın çakışık olarak içerdikleri için, analizler yerine kullanılmaları doğru bir yaklaşım değildir.

\section{Laboratuvar analizleri, yerinde muayeneler (Laboratory studies and in-situ applied}

\section{tests)}

Mimari mirasın üzerine oturduğu zemin ve bu zemine temas ettiği temellerinden üst örtüsüne kadar yapının tüm bölümleri hakkında görsel olarak elde edilebilecek verilerin ötesinde bilgilerin edinilmesi amaciyla laboratuvar analizleri ve yerinde muayeneler yapılır. Laboratuvar analizleri, yap1 malzemesinin tabiatını anlayıp, uygun nitelikte onarım malzemesini saptamak veya bir tahribat sürecinin nedeni ile ilgili ileri düzeyde bilgi sahibi olmaya yönelik olarak yapıdan alınmış farklı türde numuneler üzerinde gerçekleştirilen çeşitli sınamalar olarak tanımlanabilir.Yerinde muayeneler ise, kızılötesi görüntüleme, ultrasonik hız ölçümü testi gibi mimari mirasın üzerinde, diğer bir deyişle yerinde (in situ) uygulanan sinama ve izleme faaliyetleridir. Bunlardan, kızılötesi görüntüleme, yapının inşa edildiği malzemelerin farklı yüzey sıcaklıklarına bağlı olarak, nem sorunları hakkında veri sağlamanın ötesinde, ahşap veya çelik gibi kargir sistemin genel kurgusu içindeki farklı karakterdeki elemanların konumlarının saptanması gibi konularda da önemli veriler sağlayabilir (Titman, 2001). Ultrasonik hız ölçümü testi (Ultrasonic Pulse Velocity Test) ise beton, taş ve ahşap yap1 malzemesinin boşlukluluk durumuna bağlı olarak, dayanımı hakkında fikir oluşturmaya yardımcı olur (Shaji ve diğerleri, 2000). Genel olarak, laboratuvar analizleri ve yerinde muayenelere ilişkin raporlar, öncelikli olarak hasar analizleri olmak üzere, tüm analizler ile birlikte değerlendirilir ve müdahalelere gerekçe oluşturur. 
Yapıya uygulanacak olan tüm numune alma ve sınama işlemlerinin yapıdaki mevcut hasarı arttırmaması, yapının fiziksel ve estetik bütünlügünü bozmaması gerekir. Bu süreçte mümkün olduğunca tahribatsız sınama yöntemlerinin kullanılması tercih edilmelidir.

\section{Tarihçe çalışması ve değer analizi (Historical study and value analysis)}

Yapının tarihsel süreç içindeki yerinin, ait olduğu dönem ya da yap1 grubu içindeki yeri veya öneminin, sembolik bir öğe olarak anlamının, bünyesinde barındırdığı süsleme unsurlarının anlam ve değerinin ortaya konduğu çalışma olarak tanımlanabilir. Yaygın kullanımda "sanat tarihi raporu" olarak bilinir ve sanat tarihçisi tarafından hazırlanır. Yapının ve yakın çevresinin tarihî geçmişi hakkında bilgileri, yapının önemli ögelerinin çizim ve fotoğraflarını, yapı hakkında yapılmış kaynak taramasını içermesi istenir. Yapının tarihi ve sanatsal değeri anlatılmaya çalışılır. Pek çok durumda, koruma kurullarına onay için teslim edilen projelerin sanat tarihi raporlarında, zengin süsleme ögelerine sahip yapılarda kapsamlı raporlar hazırlandığı görülürken, daha mütevazi yapılar için daha kısa raporlar hazırlandığı görülmekte, bu durum, değer alg1sı konusunda yanıltıcı bir izlenim yaratmaktadir.

İdeal koşullarda bu raporun, konusuna hâkim bir mimarlık tarihçisi ve mimari yapıtlar üzerine çalışan bir sanat tarihçisinden oluşan bir ekip tarafından hazırlanması gerekir. Tarihçe çalışmasının müellifleri, konuyla ilgili tüm ana kaynaklara ve -varsa- basılı bibliyografyaya ulaşmış, çalışması kapsamında yapı hakkında farklı kaynaklardan edindiği bilgilere ve arşiv belgelerine mutlaka yer vermiş olmalıdırlar. Yukarıda bahsi geçen içeriğin ötesinde, yapının hangi türden değerler içerdiğine ilişkin bir değer analizi bölümü ve neden korunması gerektiğine ilişkin bir sonuç bölümünün olması gerekir. Zira burada işaret edilen değerler, koruma projesinin biçimlendirilmesinde önemli rol oynayacak, tarihçe çalışması, sadece tarihi değere referans veren bir belge olmanın ötesinde, korunması gereken tüm değerleri doğrudan işaret eden bir belge olacaktır. Değer konusu ile ilgili ulusal ve uluslararası literatürde pek çok kaynak bulunmaktadır. Bununla birlikte ICOMOS Türkiye Mimari Mirası Koruma Bildirgesi'ndeki değer tanımlarının, mimari miras için en güncel tanımlar olduğu ifade edilebilir (ICOMOS Türkiye).

\section{Araştırma veya temizlik kazıları (Excavations for further research)}

Korunması istenen mimari mirasın kısmen ya da büyük ölçüde toprağın altında kaldığı, kendi üst yapısının yıkılması sonucunda düşen parçaların içine gömüldüğü koşullarda yapinın ortaya çıkarılmasını veya yapının temellerinin muayene edilmesini gerektiren durumlarda araştırma ve temizlik kazıları gibi işlere tespit ve araştırma aşamasında ihtiyaç duyulması muhtemeldir. Rölöve alırken yeterli ve doğru tespitler yapabilmek için gerekli olan bu süreçte yapının bütünlüğünü korumak bağlamında düzenli ve sistemli çalısılması gerekecektir. Burada göz önünde bulundurulması gereken önemli bir husus, araştırma kazısına başlamadan önce ilgili Koruma Bölge Kurulu'ndan izin alınması gerekliliğidir. Amacı ya da kapsamı ne olursa olsun mimari mirasın yakınında veya koruma alanı içerisinde kazı yapmak ana mevzuata göre fiziksel müdahale kapsamındadır ve öncesinde mutlaka izin alınmasını gerektirir.

Kazı yapılacak zeminin karakterine bağlı olarak, kazı öncesinde zeminin araştırılması, özelikle katmanlı yapıya sahip yerleşimlerin bulunduğu konumlarda özel bir önem taşır. Burada GPR 
(Ground Penetrating Radar) gibi yöntemlerden faydalanılması, kazı kararının alınması, kazı sürecinin yönetilebilmesi ve yönlendirilmesi konularında önemli faydalar sağlayacaktır. Zemine yakın boşluk veya farklılaşmaları algılayabilen GPR uygulaması, yapı kalıntılarının veya kanalların kazı yapılmaksızın konum ve büyüklüklerini tespit edebilmeyi sağlar. Genel bir kural olarak, araştırma veya temizlik kazısı ile ilgili hazırlanacak olan raporlarda buluntuların niteliği ve yerleri gibi bilgilere mutlaka yer verilmesi, tüm buluntuları, konumları, yapısal özellikleri ve yerleriyle tanımlayabilecek eksiksiz bir görsel belgeleme yapılması gerekir. Bununla beraber, kazılan bölgelerin tespit çalışmaları tamamlanana dek emniyetinin sağlanması da bir başka önemli unsurdur.

\section{Sentez aşaması (Synthesis stage)}

\section{Katşılaştırmalı çalışma (Comparative analysis)}

Yapının mevcut, kısmen ya da tamamen yitirilmiş elemanları ya da özelliklerinin aynı türden, aynı dönemde ve/veya aynı coğrafyada yapılmış yapılardaki elemanlar ve özelliklerle karşılaştırılması olarak tanımlanabilir. Bu çalışma, korunması istenen mimari mirasla benzerliğe sahip yapıların çeşitli bileşenleri ve farklı kategorilerdeki özellikleri ile araştırılması üzerinden gelişir. Karşılaştırmalı çalışma için, tarihçe çalışmasındaki kaynak araştırmasını benzer yapıları da kapsayacak biçimde yapmış olmak önemlidir. Proje konusu olan yapının nadir bulunan bir yapı olması durumunda ise, dönemin mimari yaklaşımının uzantısı olan mimari bileşenlerini kavramaya yetecek düzeyde araştırma yapmak gerekir. Mimarlık tarihi, sanat tarihi ve restorasyon konularında yapılmış yayınlar, projesi hazırlanan yapı ile ilgili karşılaştırmalı çalışma için çok önemli yazılı ve görsel bilgiler içerebilir.

Karşılaştırmalı çalışmada, plan organizasyonundan detay çözümlerine kadar olan farklı ölçeklerde benzerliklerin ortaya konarak, Restitüsyon aşamasında kullanılabilecek bilgilerin elde edilmesi amaçlanır. Dönem bazında örnekleyecek olursak; korunması ve onarılması arzu edilen bir Anadolu Selçuklu kervansarayındaki, günümüze ulaşamamış bir mimari eleman, benzeri form, detay ve boyutlarda bir Anadolu Selçuklu Dönemi medresesinde hâlihazırda mevcut olabilir veya yitirilmiş olduğu halde fotoğrafla varlı̆̆1 belgelenmiş olabilir. Bu durumda o elemana ait form boyut ve malzeme gibi bilgileri edinmek ve kayıp elemanın neye benzediği hakkında fikir yürütmek mümkün hale gelir. Bu durum bir sonraki aşama olan Restitüsyon aşaması için veri oluşturur.

\section{Restitüsyon (Restitution)}

Yaygın olarak kullanılan terminolojide, yanlış biçimde "restitüsyon projesi” olarak adlandırılan süreç aslında bir proje süreci değildir. Yapının özgün durumunun ya da çeşitli dönemlerdeki yıkım ve eklemelerle farklılaşmış durumlarının, eldeki veriler ışı̆̆ında çizimlerle ortaya konduğu bir görsel sınama aşamasıdır. Restorasyon müdahalelerine ilişkin bilgi üretilen, yapı bünyesinden, tarihçe çalışmasından ve karşılaştırmalı çalışmada yer alan yapılardan toplanan bilgilerin anlam kazandığı önemli bir süreçtir. Yapının yıkık ya da kayıp kısımlarının yapı ile ilişkisi bu aşamada bilinen tüm alternatifleriyle ortaya konur. Kesinlik içermemesinden ötürü tartışmaya açıktır. Temizlik kazıları ve kaynak araştırmasından edinilen yeni bilgilerle veya uygulama sürecinde ortaya çıkan yeni bulgularla değişime uğrayabilir. 
Restitüsyon önerisi, yapının üzerinde sınamalar yaparak bilgi edinmeye yarar. Spekülatif yaklaşımlar içerdiğinden, hiçbir zaman restorasyon projesi yerine kullanılamaz. Yitik elemanın konum, malzeme, form, detay gibi özelliklerinin ne derece bilindiği önemlidir. Sayılan özellikler dikkate alınarak her yitik kısmın ne ölçüde bilindiği ile ilgili "bilinirlik seviyeleri”" adı verilen bir sınıflama oluşturulmaya çalışılır. Bu durumla ilgili analiz, restitüsyon paftalarından ayrı bir pafta olarak hazırlanır. Sonuçta ortaya çıkan kategoriler renk kodları halinde restitüsyona konu olan elemanların üzerinde belirtilir. Buna, "güvenilirlik analizi” adı verilir. Bu tanımlama, sürecin devamındaki eylem biçimini saptamak için özel bir önem taşır. Zira ancak hakkında güvenilir bilgi olan, bilinirlik düzeyi yüksek bir yitik ögenin, proje önerisi sürecinde tamamen yeniden inşası öngörülebilir.

\section{Öneri aşaması (Proposal stage)}

Öneri aşamasında günümüzde nasıl kullanılabileceğine ilişkin sınama ve önerileri içeren proje sunulur. Yeniden işlevlendirme analizlerin hazırlanması, işlev önerisi ve müdahale kararlarını içeren bu aşama, yaygın biçimde, restorasyon projesi olarak bilinmesine rağmen her zaman bir restorasyon sürecini içermeyebilir. Yapının güçlendirilerek mevcut haliyle korunması, belirgin yeni bir işlev verilmesi önerilmeyebilir. Öneri süreci, yapının gündelik hayattaki yeni varoluş biçiminin gereği olan müdahaleleri ne derece tolere edebileceği, genel fiziksel durumu, yeniden inşa edilmesi gereken kısımların bilinirliği ve koruma mimarının sürece yaklaşım biçimi ile doğrudan ilişkilidir.

\section{Müdahale kararlar1 (Decisions on intervention)}

Bozulma süreçlerini durdurmaya, tehlike arz eden kısımlardaki tehlikenin giderilmesine yönelik yapı ve malzeme ölçeğinde tüm müdahale kararları bu kapsamdadır. Yapının mevcudiyetini sürdürebilmesi ve kültür varllğı olarak gelecek nesillere intikal ettirilebilmesi için birinci derecede önem taşıyan bu kararlar, uygulama yerleri ve açıklamalarıyla birlikte rölöve paftaları üzerinde gösterilir.

Ülkemizde, mimari mirasa müdahalenin biçim ve yöntemleri konuda bilgi temin etmeye yönelik bir kaynak sıkıntısının olduğu gözlenmiştir. Öte yandan, bu sorununun son yıllarda yerli kaynaklarla çözüme kavuşturulmaya başlandığı da izlenebilmektedir. Buna bir örnek olarak verebileceğimiz, L. Zakar ve K. Eyüpgiller'in birlikte hazırlamış olduğu eser, yapısal sorunlar, malzeme sorunları ve bunlara müdahale yöntemleri ile ilgili temel bilgileri ve örnekli açıklamaları içeren güncel bir Türkçe kaynak olarak önemlidir (Zakar ve Eyüpgiller, 2018).

\section{Yeniden islevlenditme analizleri (Analysis for a new function proposal)}

Bu bölümdeki analizler "Analizler” başlığı altında yer alan analizlerden farklı olup onarılan mirasın yeni fiziksel durumuna uygun bir işlevin uygulanabilmesini kolaylaştıracak hesaplamaları ve öngörüleri içerir. Yapının paftalar üzerindeki ya da bilgisayar ortamındaki onarılmış hali üzerinden yapılabilir. Özellikle geniş programlı yapıların korunması sürecinde büyük fayda sağlar. Zira, korunması istenen yapının içerdiği farklı nitelikteki hacimlerin sayısı, çeşitliliği ve bununla orantılı olarak büyüklügü artıkça, bu analizlerin yapılması önem kazanmaya başlar. Ulaşım ve gün 1şığı ile aydınlanma analizlerinin yapılması, bu hacimlerin yeni işlev önerisinde doğru biçimde değerlendirilebilmesi için olumlu katkılar sağlar. Ulaşım analizi, yapının yaklaşım ve giriş 
noktalarından yapı bünyesindeki tüm hacimlere ayrı ayrı nasıl ulaşılabileceğini, mekânlar arasındaki geçişleri ve buna bağlı mekânsal ilişkileri gösterecektir. Bu analiz yardımıyla girişe en yakın veya en rahat ulaşılan mekânlar ile en uzak veya mahrem bölümleri ortaya koymak, yeni işlev önerisindeki mimari programın ögelerini bu durumu dikkate alarak yerleştirmek mümkündür. Gün 1şığ1 ile aydınlatma analizi günün hangi saatinde hangi iç mekânda nasıl bir aydınlık düzeyi oluşabileceği hakkında fikir verir. Benzeri biçimde mekân büyüklüklerinin ve farklı niteliklerinin ortaya konduğu analiz paftaları yardımıyla yeni işlev ile bağdaştırılacak onarım sonrası koşullar, mekân bazında ortaya konabilir.

\section{Yeni işlev ve yeni işlevin gereksinimlerine yönelik müdahale kararları (Interventions for the new function)}

İşlev ile ilgili ilk karar yapıya işlev verilip verilmeyeceğidir. İşlev verilmesi mimari mirasın korunması sürecinde yapıya ve yakın çevresine sahip çıkılmasını, yapının ve yakın çevresinin temiz tutulup bakımının yapılmasını sağlar. Bununla beraber yeni işlev önerisi, yapının fiziksel durumuna ve mekânsal niteliklerine uygun olmadığında yapı ve yakın çevresinde yeni sorunlara da neden olabilir. Bu bağlamda, işlev vermeye yönelik müdahaleler yapılması durumunda yapının özgünlügüne ve sembolik değerine büyük ölçüde zarar verilmesi ihtimali oluşabilir. Kısaca, koruma sürecinde işlev vermek kadar işlev vermemek de önemli ve gerekli bir karardır. Yapının ekonomik değerini öne çıkaran faydacı yaklaşımlardan kaçınılması gerekir.

Yapıya verilecek yeni işlev bu işlevin çağdaş yaşamdaki karşllı̆ı olan bazı gereksinimleri de beraberinde getirecektir. Özgün hacimlerin yeterli olmaması durumunda ilave edilebilecek ek yap1 ve müştemilatlar, ilave üst örtü, özellikle elektrik, sıhhi tesisat ve ssıtma sistemi hatları, bu hatlara bağlı dağılım elemanlarının konumlandırılması önemli müdahalelerdir. Bahsi geçen tüm bu müdahalelerin uygulanmasında yapının özgün kısımlarını gölgeleyip tahrip etmeksizin, görsel ve fiziksel kirliliğe yol açmaksızın uygulama yapmak esastır. Kültür mirasına yönelik uygulanacak bu türden müdahalelerin olabildiği ölçüde yapı bünyesinde kalıcı izler bırakmayacak ve geri dönüşü mümkün şekilde yapılması şarttır. Yukarıda 2.2.2. başlığında bahsettiğimiz Venedik Tüzüğü’nün 13.maddesinde bu durum şu şekilde açıklanmaktadır: "Eklemelere ancak, yapının ilgi çekici bölümlerine, geleneksel konumuna, kompozisyonun dengesine ve çevresiyle olan bağlantısına zarar gelmediği hallerde izin verilebilir" (Erder, 2007, s.242). Koruma onarım projelerinin yapılması kadar uygulanmasının da her aşamada uzmanlık gerektirdiği, özellikle uygulama süreçlerinin planlanmasının ve denetim altında tutulmasının çok önemli olduğu her zaman hatırda tutulmalıdır.

\section{Proje önerisi (Project proposal)}

Genel olarak, onarılması düşünülen yapının onarım ve müdahalelerden sonraki durumunun, yeni işlev önerisiyle ilgili unsurları da içeren açıklamalarıyla birlikte çizimler, canlandırmalar ve maketlerle sunulmasından ibarettir. Bu süreçte tesisat, elektrik ve mekanik projeleri de hazırlanır. Mimarın organizatör yönü bu aşamada özellikle önemlidir. Yeni işlevin gereği elektrik ve sıhhi tesisat ögelerinin montaj biçiminin ve kullanımının koruma müdahaleleri ile uyumunu denetlemek mimarın görevidir. 


\section{PROJELENDİRME SÜRECİNE İLİŞKİN ÖNERİ İLKELER (PROPOSED PRINCIPALS FOR PROJECT PREPARATION PROCESS)}

Bu bölümde yukarıda aşamaları hakkında bilgi verilen projelendirme sürecine katkıda bulunması öngörülen on ilke önerilmiş ve bunlarla ilgili açıklamalara yer verilmiştir. Bunlar; korumanın daimi önceliği, vaka bazında yaklaşım, bilimsel yaklaşım, multidisipliner ve katılımcıllğa açı yaklaşım, mevzuatla etkileşim, uygulanabilirlik, süreklilik ve tutarlılık, sayg1, etiğe uygunluk, mimarın sorumluluğu ilkeleridir.

\section{Korumanın daimi önceliği (Permanent priority of conservation)}

Öncelikli amacın onarılan yapıdan ya da onarım sürecinden çeşitli biçimlerde maddi kazanç sağlamak değil, kültür mirasının sahip olduğu tüm değerleriyle korunarak gelecek nesillere intikal ettirilmesi, önerilen projelerde bu durumun sürekli olarak gözetilmesi olmalıdır. Türkiye özelinde bakıldığında, geçmişten bugüne yasal düzenlemelerin ana vurgusunun bu olduğu, öte yandan, anlayış, yaklaşım, eylem ve yöntem konularında eğitim ve kültür bağlamında çeşitli sorunlarla karşılaşıldığı görülür.

\section{Vaka bazında yaklaşım (Case by case approach)}

Her mimari mirasın farklı bir öyküsünün olması nedeniyle koruma yaklaşımları örnek bazında farklılık gösterir. Aynı türden, aynı dönemde yapılmış, aynı coğrafyadaki iki yapının sorunlarının benzeşmesine karşın, bu sorunlar hiçbir zaman birebir aynı değildir. Her vakanın tarihi, sorunları ve potansiyelleri bağlamında bilimsel olarak incelenmesi ve özellikle proje müellifleri tarafindan vaka bazlı yaklaşımın benimsenmesi ve bu yaklaşımın gerekçesinin, tüm koruma paydaşlarına ve özellikle işverene izah edilmesi gerekir. Öte yandan bu durumun Türkiye'deki koruma ile ilgili yaklaşımlarda ne derece dikkate alındığ1 tartışma konusudur. İşlev bağlamında, büyük ölçekli her geleneksel konut örneğini butik otel, her eski mabedi kültür merkezi yapmaya çalışmak gibi, yerel yönetimlerde benzerleri sıkça görülen türden yaklaşımlar, koruma bağlamında yapıcı olmaktan uzak olup yeni sorunlara neden olma ihtimalleri fazladır. Aynı türden yapıların farklı mimari mekân organizasyonları, farklı büyüklükleri, farklı sorunları ve farklılık gösteren diğer pek çok başka nitelikleri olabilir. Uygulanacak yöntem ve verilecek işlev de buna göre farklılaşmalıdır.

\section{Bilimsel yaklaşım (Scientific approach)}

Günümüzde koruma konusu bilimsel koruma bağlamında gelişmektedir. Bilimsel yaklaşım, bildik kuralların sorgulandığ1, sorunların ölçülebilir değerler üzerinden ortaya konduğu, sebep sonuç ilişkilerinin kurulmaya çalışıldığı, farklı yöntemlerin denenerek sonuçları üzerinden tartışmaların yapıldığ1, rasyonel bir süreç olarak tanımlanabilir. Uluslararası alanda bu düşünce yeni olmayıp, geçmişi 1960’lı yıllara kadar uzanır. Venedik Tüzüğü’nün (1964) 2.maddesi, “mimari mirasın incelenmesine ve korunmasına yardımcı olabilecek bütün bilim ve tekniklerden” faydalanılmasını öngörmektedir (Erder, 2007, s.241). Günümüzde durum biraz daha farklıdır. Vinas’a (2005) göre, bugünün çağdaş koruma anlayışı, sadece bilimsel verilerin yönlendirdiği ve herhangi bir teoretik gövdenin bilimsel yaklaşımın önüne geçemediği bir koruma yaklaşımını öngörecek kadar ileri gitmiştir (s.90). Koruma proje ve uygulama süreçlerine hakimiyeti her ne düzeyde olursa olsun, 
bilimsel yaklaşımın varlığı, farklı ölçek ve içeriğe sahip işlerle ilgilenecek, farklı disiplinlerden uzmanların yer aldığı bir ortamı da kaçınılmaz olarak beraberinde getirecektir.

Proje ve uygulama süreçlerinde, restitüsyon ile restorasyonun net biçimde ayrılması, spekülatif yaklaşımlardan ve tarihselci tutumlardan kaçınılması da bu yaklaşımın önemli bir parçasıdır. Proje sürecinin tarihçe çalışması kısmında da belirtildiği üzere, tarihi belgeler ve çeşitli kaynaklardan edinilmiş bilgiler son derece önemli olup koruma ile ilgili yaklaşımları belirlemelidir. Bununla beraber bu bilgi ve belgelerin özgünlüğünün ve tutarlıllğının sınanması, içerik karşılaştırmalarının yapılması gibi yöntemlerden de uzaklaşılmaması gerekir.

Bilimsel yaklaşım denilince, ilginç bir biçimde, ilk akla gelenlerden biri teknolojinin nimetlerinden faydalanmaktır. Bununla birlikte bilimsel yaklaşım sadece teknolojik ürünler kullanılarak sağlanabilecek bir koşul değildir. Özellikle son otuz yılda büyük bir hızla gelişen teknolojinin, malzeme, yöntem, sunum ve analiz gibi pek çok konuda yenilikler sunmuş olmasına karşın, korumanın öncelikle tespitlerin yapılmasını ve müdahalelerin tespitlerin sonuçlarına göre geliştirilmesini sağlayan temel yaklaşımı değişmez. Gelişen teknoloji, korumanın bilimsel süreçlerine tespitlerde hız ve hassasiyet konularında katkıda bulunurken yeni yöntemlerin sağladığ1 yeni bilgilerle alınan kararların etkinliğini arttıracaktır. Bunun koruma bağlamında pek çok alanda örneklerini görmekteyiz. İnşaat mühendisleri, bilgisayar kullanımının yaygınlaşmasından önce taşıyıcı sistem sorunlarını iki boyutlu çizimler veya perspex maketler kullanarak tartışmaya çalışırken, günümüzde, yapıların bilgisayar modellemeleri üzerinden, yapıların üzerinde oluşan yüklerin ve gerilimlerin yapıların farklı bölgelerine göre dağılımlarını inceleyebilmektedirler. Muhtemelen birkaç yıl içerisinde, BIM uygulamalarının koruma proje ve uygulama süreçlerinde yerini alması yeni ufuklar açacaktır (Lopez ve diğerleri, 2018, s.11). Rölöve, analizler ve raporlar, bilgisayar ortamında entegre bir arayüz üzerinde bir arada değerlendirilebilecek ve hatta belki de yapılması planlanan müdahalelerin etkileri, yine bu ortamla ilişkilendirilmiş simülasyonlar üzerinden görülebilecektir. Sonuçta, gelişen teknoloji sayesinde sağlananlar, koruma süreçlerinde sürat, hassasiyet ve önceden görülemeyeni görmek gibi konular bağlamında bilimsel yaklaşıma katkıdan ibarettir.

\section{Multidisipliner ve katılımcılığa açık yaklaşım (Multidisciplinary and open-minded approach)}

Mimari mirasın koruması ile ilgili proje ve uygulama süreçleri, birbirinden çok farklı sorunları barındıran yapıları nedeniyle çok disiplinli bir yaklaşıma ihtiyaç gösterir. Mimarın bir organizatör olarak, bu durumun bilincinde olması gerekir. Örneğin, konservatör ve inşaat mühendisi çoğu zaman proje ve uygulama ekiplerinin ayrılmaz parçalandır. Öte yandan bu ekibin iletişim kurabilmesi için aynı dilden konuşmaları, aynı endişeleri paylaşmaları gerekir. Burada ilk olarak akla, çini gibi özel parçaların konservasyonu ve renovasyonu üzerine çalışan bir malzeme bilimci, zemin veya statik ile ilgili sorunlarda bilgisine başvurulacak bir jeoloji mühendisi veya inşaat mühendisi, yapı ile çevresinin geçmişini araştırabilecek bir tarihçi gibi önemli disiplinlerden uzmanlar gelmesine rağmen, yerine göre bir halkla ilişkiler uzmanı veya toplumbilimci de koruma süreçlerinin parçası olabilmektedir. 
Koruma ile ilgili süreçlerin neler olduğunun ve nasıl işlediğinin topluma anlatılması, yapılan zahmetli işlerin toplum tarafindan kıymetlendirilmesini ve yeni koruma çalışmalarının toplum tarafından desteklenmesini sağlayacaktır. Burada İngiliz sanat tarihçisi Simon Thurley'nin English Heritage için stratejik program olarak sunduğu kültür mirası koruma döngüsünden kısaca bahsetmek, konunun önemini anlamak açısından faydalı olacaktır (Şekil.1). Bahsi geçen döngü, tarihi çevre üzerinden gelişen, birbirini tetikleyen anlamak (understanding), değer vermek (valuing), ilgi duyup korumak (caring) ve keyif almak (enjoying) kavramları üzerine kuruludur (Thurley, 2015). Toplum, kültür mirasını anladıkça ona değer atfeder. Kültür mirasına değer atfeden toplum ona ilgi duyar ve onu korur. Kültür mirasına ilgi duyan toplum ondan keyif alır ve keyif alınmasını sağlar. Keyif almak ise kültür mirasını anlamak için istek uyandırır ve böylece döngü tamamlanır. Sadece bu stratejik model bile koruma konusuna İngiltere'nin bakışındaki toplum odaklı yaklaşımı göstermesi bakımından dikkate değerdir. Bununla birlikte Türkiye'de bunun tam tersi bir yaklaşım mevcuttur. 1961 ve 1982 Anayasa'larıyla kültür mirasını koruma görevini devlete verilmiş olup, 1983 yılında kabul edilmiş ve halen de yürürlükte olan 2863 sayılı Kültür ve Tabiat Varlıklarını Koruma Kanunu'nda kültür mirası bilinci oluşturulması ve koruma süreçlerine halkın veya bu amaçla oluşturulmuş sivil toplum örgütlerinin katılımı ile ilgili herhangi bir madde yer almamaktadır. $\mathrm{Bu}$ durumun düzeltilmesi konusunda koruma ile ilgilenen tüm uzmanların mevzuatla etkileşim süreci içinde yer almaları gerekecektir.

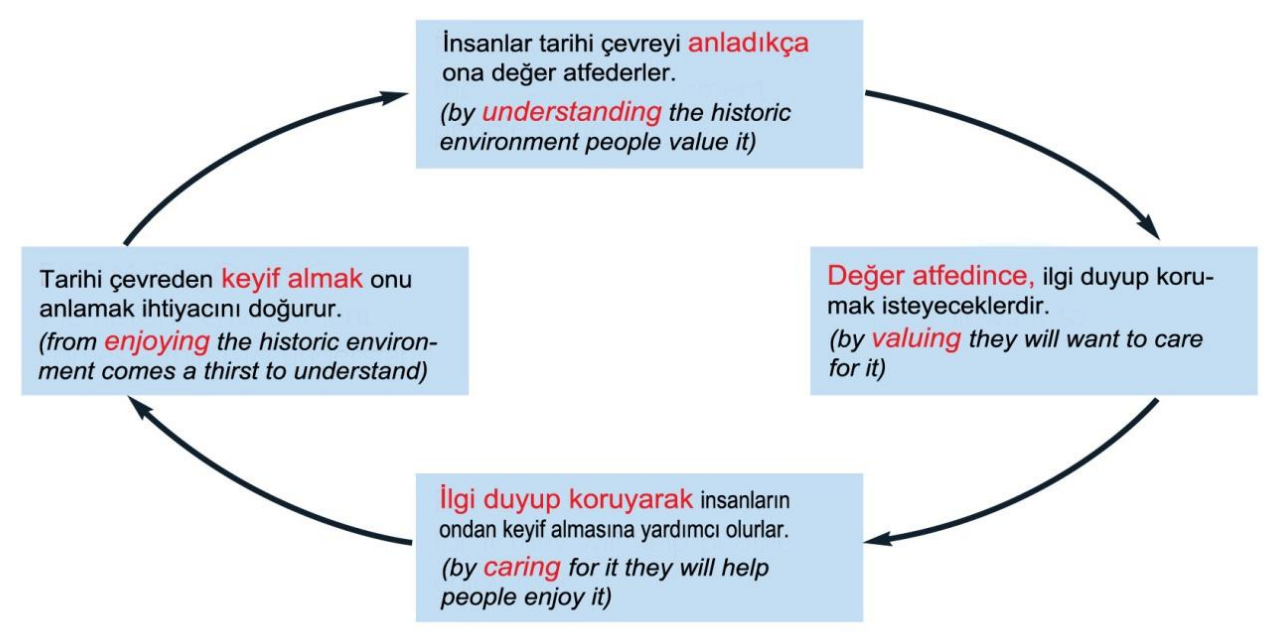

Şekil 1. Kültür mirasını koruma döngüsü (Thurley, 2015).

\section{Mevzuatla etkileşim (Interaction with legislation)}

Mevzuata uymak, Türkiye'deki ilgili mevzuatın mevcudiyetine bağlı bir zorunluluk olarak anlaşılmaktadır. Bununla birlikte, proje ve uygulama süreçlerinde, kanun ve yüksek kurul ilke kararlarına uygun olduğu kadar, uluslararası anlaşmalara ve çağdaş yaklaşımın ifadesi olan uluslararası metinlere de uygun bir yaklaşımın benimsenmesi şarttır.

Uluslararası metinler, kültürel mirasın korunması alanında pek çok ülkenin imzasıyla kabul edilmiş sözleşmeler olup, bir kısmı Türkiye Cumhuriyeti tarafından da benimsenerek iç hukuk metni haline 
getirilmiştir. Bunların, konumuzla ilgili olan en önemlisi, mimari mirasa müdahale biçim ve ölçütlerini belirleyen 1964 tarihli Venedik Tüzüğü'dür. Gayrimenkul Eski Eserler ve Anıtlar Yüksek Kurulu tarafindan, 24.09.1967 tarihinde, kurulun 3674 sayılı kararı ile kabul edilmiştir (Erder, 2007, s.243). Dünya Kültürel ve Doğal Mirasının Korunmasına Dair Sözleşme, 1972 yılında UNESCO'nun 17.Genel Kurulu'nda kabul edilmiş bir diğer metindir. Birleşmiş Milletler Eğitim ve Kültür Örgütü çerçevesinde hükümetlerarası bir Dünya Mirası Komitesi kurulması, koruma için uluslararası fon oluşturulması gibi kararların ötesinde sözleşmeye imza koyan hükümetlerin, eğitim ve korumanın özendirilmesine yönelik hükümleri bulunmaktadır. 1982 yılında 2658 sayılı kanunla Türkiye Cumhuriyeti’nin, Dünya Kültürel ve Doğal Mirasının Korunmasına Dair Sözleşme’ye katılması uygun bulunmuştur (Asatekin, 2004, s.86). Bir başka önemli metin, Türkiye Cumhuriyeti’nin benimseyip hazırlık süreçlerine de katıldığ1 1975 tarihli Amsterdam Bildirgesi'dir. Korumada anlayış ve kapsam değişikliği getiren belge, korumanın sadece mimarın işi olmadığını ortaya koyması, korumayı kent/alan ölçeğine taşıyan bir anlayışla, bu çalışmanın 3.4. başlığında bahsi geçen katılımcı yaklaşımın ve eğitimin önemini vurgulayan bir belge olması bakımından önemlidir (Asatekin, 2004, s.81). Öte yandan, bildirgede altı çizilen konuların ulusal mevzuatta ne kadar hayata geçirilebildiği tartışma konusudur. Ulusal mevzuatımızdaki durumu bilinmemekle beraber, burada Nara Belgesinden de bahsetmek faydalı olacaktır. 1994 yllında Nara Japonya'da Nara Özgünlük Konferansı'na katılan 45 katılımcı tarafindan imzalanan belgede, kültürel mirasa atfedilen değerlerin mirasın özgünlüğü ile bağlantısı üzerinde durulmaktadır (Asatekin, 2004, s.8285). Bu durumun proje ve uygulamalardaki karşllı̆ı̆, yapının yıpranmış özgün bölüm ve elemanlarının yenilenmesi yerine olabildiğince korunmaya ve takviye edilmeye çalışılmasıdır.

Ulusal mevzuatın en üst noktasında Anayasa'nın ilgili maddesi yer alır. Anayasanın XI. bölümünde “Tarih, Kültür ve Tabiat Varlıklarının Korunması” başlığı altında, 63. Madde'de "Devlet, tarih, kültür ve tabiat varlıklarının ve değerlerinin korunmasını sağlar, bu amaçla destekleyici ve teşvik edici tedbirleri alır. Bu varlıklar ve değerlerden özel mülkiyet konusu olanlara getirilecek sınırlamalar ve bu nedenle hak sahiplerine yapılacak yardımlar ve tanınacak muafiyetler kanunla düzenlenir.” hükümleri yer almaktadır. Kültür mirasının korunması konusundaki ana mevzuat ise 1983 yılında yürürlüğe girmiş, üzerinde pek çok değişiklikler yapılmış olduğu halde halen yürürlükte olan 2863 sayılı Kültür ve Tabiat Varlıklarını Koruma Kanunu'dur. Kanuna göre, devletin kültür mirası ile ilgili faaliyetleri Kültür ve Turizm Bakanlığı tarafindan koordine edilmekte, ilgili yönetmelikler ve bakanlığa bağlı kurulların kararları doğrultusunda, devletin ilgili birimleri tarafindan yürütülmektedir. 2005 yllında 5366 sayll Yipranan Tarihi ve Kültürel Taşınmaz Varlıkların Yenilenerek Korunması ve Yaşatılarak Kullanılması Hakkında Kanun yürürlüğe girmiştir. Koruma niteliği tartışmalı olan bu yasa, sit alanı ilan edilmiş kent parçalarının yeniden düzenlenmeleriyle ilgilidir. Bu yasaya ve 2863 sayılı yasada 2004 yılında yapılan değişikliklere tepki olarak 2013 yılında ICOMOS Türkiye Mimari Mirası Koruma Bildirgesi yayımlanmıştır. Bu belgede ulusal mevzuatımızda karşılığını bulamamış tanımlara ve değer tanımlarına yer verilmiş, mimari mirasın değerlendirilmesine yönelik süreçler, müdahale ilkeleri ve biçimleri tanımlanmış, koruma ile ilgili olarak örgün ve yaygın eğitimin rolü vurgulanmıştır (ICOMOS Türkiye).

Yukarıda bahsi geçen ve farklı alanlarda Türkiye'deki koruma proje ve uygulamalarına katkı sağlayan, tüm ulusal ve uluslararası metinleri gözeterek doğru kararlar verebilmek ve uygulama yapabilmek, konu hakkında bilgi sahibi olmaya bağlı olarak gelişecek bir süreç olabilir. Bu bağlamda 
bu çalışmanın "Mimarın sorumluluğu” başlığı altında önerilen mimarın sorumluluğu ilkesi, özellikle mimarın eğitimi konusu önem taşımaktadır.

Türkiye'de mimari mirasın korunması ile ilgili güncel süreçler, 2863 sayılı Kültür ve Tabiat Varlıkları Kanunu'ndaki hükümlere göre biçimlendirilmiş, proje ve uygulama süreçleri ile ilgili hususlar ise T.C. Kültür Bakanlığ1 Kültür ve Tabiat Varlıklarını Koruma Yüksek Kurulu'nun 660 numaralı ilke kararıly düzenlenmiştir. Türkiye'de kültür mirasının korunması ile ilgili olarak her konuda hükümler içeren yoğun içerikli bir kanunun mevcut olmasına rağmen, bu kanunun ilk kabul tarihinden bugüne, çözülememiş önemli kapsam ve yaklaşım sorunlarını barındırdı̆̆ı da bilinmektedir. Kanunda modern mimarlık mirası, endüstri mirası gibi kavramların karşıllı̆ı olan yapıların, kanunun 6. maddesinde yer alan 19.yüzyıl ayrımına göre kapsam dışı bırakılmaları, korunacak kültür mirası ile ilgili olarak kanunun 7. maddesinde açık olmayan bir sayıca yeterlilik sınırı tanımlanmış olması ve koruma kararına esas oluşturacak değerler ile ilgili yeterli bir tanıma yer verilmemiş olması, bunların ilk akla gelenlerindendir. Halkın koruma konusunda bilinçlendirilmesi ve koruma süreçlerine halkın katılımı konularında herhangi bir hüküm içermiyor olması da, halen yürürlükte olan kanunun, koruma konusunda söz sahibi olan ülkelerdeki güncel yaklaşım ve uygulamalardan ne denli uzak olduğunun bir göstergesidir. Kanundaki bu ciddi sorunlarla ilgili olarak güncel anlayışı ve edinilmiş tecrübeleri baz alan bir geri besleme süreci de işletilememiş veya işletilmemiş olmalıdır. Takip edilmesi gereken yaklaşım, mevcut sorunların çözümüne ve eksikliklerin giderilmesine yönelik güncellemeleri yapmak için, örgütlü bir çaba ile sürekli olarak bir geri besleme süreci oluşturmaya yönelik çalışmaktır. Bu konuda yasada gereken değişikliğin yapılması için baskı oluşturulması gerekir. Bu baskı unsurunu farklı kanallardan oluşturmak için, koruma sürecinde emek veren tüm disiplinler ve bunun yanı sıra mimarlar da çaba sarf etmelidir. Böylece mevzuata tek taraflı uyum, mevzuatla etkileşime dönüşebilir, kanuni süreçlerin koruma anlamında daha verimli işletilmesi sağlanabilir.

\section{Uygulanabilirlik (Applicability)}

Proje süreçlerindeki tüm müdahale önerilerinin, bilinçli bir şekilde, muhtemel uygulama sorunlarının varlığı dikkate alınarak ve önerilen müdahalelerin muhtemel sonuçları düşünülerek yapılması gerekir. Bu durum proje ve uygulamacıların özellikle yapım bilgisi konusundaki yetkinlikleriyle ilgili olup açıça bir eğitim ve tecrübe sorunudur.

Eğer özgün yapım tekniği ve malzeme ile onarım öngörülmüşse özgün yapım tekniğini uygulayabilecek zanaat erbabının ve özgün malzemenin bulunabilirliği mutlaka dikkate alınmalıdır. $\mathrm{Bu}$ husus, mimari mirasın özgün yapım tekniği ve malzemeleri ile ilgili katalog ve performans çalışmalarının yapılmasını da zorunlu hale getirmektedir. Ülkemizde halen bu konuya gereken önemin verilmediği görülmektedir. Literatürde Türkiye'nin bölgeleri bazında özgün yap1 tekniğine ilişkin çalışmalar son derece sınırlı sayıdadır. Örneğin, 1998 yılında basılmış olan Geleneksel Türk Evleri Bibliyografyası'nda (Kahya, 1998), malzeme konu başlığı altında kitap, makale ve tezlerden oluşan, en eskisi 1949 tarihli toplam 97 eserin adı geçmekte olup bunların sadece 81’inin doğrudan konuyla ilgili olduğu görülmektedir. Bu 81 çalışmanın büyük çoğunluğu ahşap malzeme ile ilgilidir. N. Sönmez’in Yapı Malzeme Terimleri Sözlüğü (1997), C.E. Arseven’in Istllâhât-1 Mimariyye’si (2017) gibi eserlerden daha fazlasına ihtiyacımız vardır. Ayrıca somut olmayan kültür mirası kavramı yerli literatüre girmiş olmasına rağmen, yapım teknikleri, somut olmayan kültür mirası olarak 
belgelenmemiştir. Günümüzde hem Vakıflar Genel Müdürlügü’ne hem de doğrudan Kültür Bakanlığ1 Kültür Varlıkları ve Müzeler Genel Müdürlügü’ne bağlı müzeler mevcut olup, taşınmaz mimari mirasla herhangi bir nedenle fiziksel ilişkisi koparılmış parçalar bu müzelerde sergilenebilmektedir (Vakiflar Gene). Bununla birlikte, tam olarak anlaşllamayan nedenlerden ötürü, müzelerden ve konservasyon laboratuvarlarından malzeme seçimi ve kullanımı konusunda edinilmiş pek çok farklı türde bilgi proje süreçlerine aktarılamamaktadır.

\section{Süreklilik ve tutarlılık (Continuity and coherence)}

Tutarlılık, projedeki tüm müdahale önerilerinin daha önceki ve daha sonraki aşamalarda yapılan tespit ve araştırmalarla bağlantılı olarak geliştirilmiş olmasıdır. Örneğin; yapısal hasar ve malzeme bozulma analizinde hasarlı olduğu ifade edilmiş bir yapı elemanının müdahale paftasında uygun bir müdahale biçimiyle karşııı bulması gerekir. Bununla birlikte, yapının farklı bölümlerine yapılan müdahalelerin de, korumaya yönelik proje müellifince belirlenmiş genel yaklaşımla uyum içerisinde olması gerekir. Benzeri biçimde, kırılgan dokusu nedeniyle minimum müdahale ile korunabilmesi mümkün olan bir yapıda geniş kapsamlı bir rekonstrüksiyon uygulanması düşünülemez.

Projelendirme sürecindeki tutarllık ve sürekliliğin geriye doğru da işletilebilmesi çok önemlidir. Proje süreci, uygulama aşamasına geçilmesi ile tamamlanmış sayılmaz. Tespit aşamasında görülemeyen bir durumun uygulama sürecinde ortaya çıkması, onarıma yönelik projenin gözden geçirilerek tekrar ele alınmasını ve gerekli değişikliklerin mutlaka yapılmasını gerektirir. Bu konunun ulusal mevzuatta da karşıllğı bulunmaktadır. T.C. Kültür ve Turizm Bakanlığ1 Kültür ve Tabiat Varlıklarını Koruma Yüksek Kurulu'nun 660 sayılı ilke kararında Esaslı Onarım İlkeleri kısmındaki (d) paragrafinda: "Restorasyon projesine temel olacak restitüsyon çalışmasının sıva raspası, kısmi söküm, sondaj, belgeler üzerinde çalışma ve karşılaştırmalı araştırmalar sonucuna dayalı olarak hazırlanmasına, onarıma başlamadan önce bu çalışmanın yapılması olanaksız ise onarım projesinin onaylanmasından sonra ortaya çıkan yeni veriler ışığında, restorasyon projesi üzerinde tadilat yapılarak yeniden koruma kurulunun onayına sunulmasına” karar verildiği ifade edilmektedir.

Koruma projesi süreci tabiatı itibariyle aslında tamamlanmamış veya esnek olarak tanımlayabileceğimiz bir süreç olup geri beslemelerle güncellenebilir yapıdadır. Bunun yanı sıra, bakım kavramı da koruma süreçleri içerisinde tutarlılık ve süreklilik bağlamında, en az proje ve uygulama kadar önem taşımaktadır. Unutmamak gerekir ki tüm Anadolu Selçuklu ve Osmanlı Dönemi anıtlarının günümüze ulaşabilme nedeni belirgin bir süreklilik içinde temizlik ve bakım yapılmasıdır. Yapıyı süpürerek temizlemekten, çatı kaplamasının kurşunlarını yenilemeye kadar değişen ölçek ve karmaşıklıkta olan tüm işler, mimari mirasın yok oluş sürecinde yapılmış birer erteleme, gelecek nesillere ulaştırılması sürecinde ileriye doğru atılmış birer adım olarak değerlendirilmelidir. Konutlar için de benzeri tespitleri yapabilmekteyiz. Say1 olarak mimari mirasımızın büyük bölümünü oluşturan bu yapılar sahipleri tarafindan yapılan çeşitli onarım ve yenilemelerle günümüze ulaşabilmiştir. Bu onarımların yöntem ve biçimine ilişkin bilgileri yazılı kaynaklarda da bulabilmekteyiz (Üredi, 2009, s.41-42). Bakım ve buna bağlı yenilemeler ile ilgili resmi prosedür ise Kültür ve Tabiat Varlıklarını Koruma Yüksek Kurulu'nun 660 sayılı ilke kararında "basit onarım" terimi kapsamında yer almakta, buna göre mimari mirasın yıpranan kapı pencere ve çatı gibi bölümleri formu ve malzemesi aynı kalmak şartıyla, ilgili Koruma Bölge Kurulu onayıyla yenilenebilmektedir. Bütün bu tecrübeler dikkate alınarak, koruma projelerinde, projedeki 
müdahalelerin sürekliliğini sağlayacak bir bakım süreci önermek, sürekliliği sağlayacak bu denli önemli bir işi sadece bir ilke kararının yeterince tanımlanmamış kapsamıyla sınırlamamak, mantıklı ve sorumlu bir yaklaşım biçimi olabilir. Zira mimari mirasın ihtiyaç duyduğu bakım ve onarım bazı durumlarda Koruma Bölge Kurulları önerisiyle yeni çözümler oluşturularak yapılmakta ve bu durumun tartışmalı sonuçları ortaya çıkabilmektedir.

\section{Sayg1 (Respect)}

Mimarın koruma süreçlerinde genel olarak alçakgönüllü bir tutum izlemesi beklenir. Bu durum tasarım süreçlerinde genel olarak izlenen tutumdan farklı olarak mimarın bildik dominant rolünün ikinci plana atıldığı, tasarımın önceliklerinin, kapsam ve içeriğinin, uyum, işlev ve sergileme endişeleriyle değişime uğradığı bir sürecin gereğidir. Bu yaklaşım biçimi yeni olmayıp, tarihi 19.yüzyıla kadar uzanmaktadır. C. Boito bu durumu şu sözlerle ifade etmektedir: "Günümüz sanatçısı anıtın önünde ne kadar eğilir, ne kadar dize gelir, ne kadar silinirse o kadar iyi yapar ödevini. Yeniden dikilip, başını kaldırdığı ve Ben de varım! Diye haykırdığı gün, işte o gün titrer eski bina..” (Boito, 2018).

Yapının bünyesindeki tüm izlere, tüm özgün niteliklerine sayg1 (özgün malzeme, özgün yapım sistemi, özgün mekân organizasyonu vb.) gösterilmesi gerekir. Keyfi, özensiz ya da dikkatsiz müdahalelerle yapının özgün niteliklerinin bozulmaması gerekir. Bunun için de yapıyı yeterli derecede inceleyip onu değerli kılan nitelikleri ortaya koymuş olmak gerekir. Bu görüşün de temelleri de 19.yüzyıla dayanmakta olup bu konudaki ilk tartışmaları ortaya koyan Emmanuel Violet-Le-Duc'tür (Erder, 1972, s.9).

Yapının tüm değerlerinin yanı sıra eskilik veya yaş değerine sayg1 duymak gerekir. Önerilecek müdahalelerde amaç yapıyı yepyeni bir görünüme büründürmek olmamalıdır. Sosyal ve politik olayların yapı bünyesinde oluşturduğu tahribat ve değişiklik niteliğindeki izlerin birer tarihi belge olarak korunması gerekir. Bu konudaki ilk detaylı tartışmayı, eskilik değeri ve tarihi değer kavramlarını ortaya koyan Avusturyalı sanat tarihçisi Alois Riegl olmuştur (Riegl, 2015, s.67-75). 20.yüzyıl başında ortaya konulmuş ve 1980'lerin koruma anlayışını şekillendirmiş bu düşüncelere günümüzün koruma projelerinde itibar edilmediği acı bir biçimde izlenmektedir. Eskilik değeri bağlamında öne çıkan bir başka unsur da özgünlüktür. Onarımlarda sıkça tercih edilen, yıpranmış kısmı iyileştirmek ve/veya takviye etmek ya da yıpranmışlğıyla muhafaza etmek yerine yok edip yerine yenisini yapma davranışı, mimari mirasın eskilik veya yaş değerine saygı duymamak anlamına gelir. Özgünlüğe saygı duyulması, yukarıda a geçen Nara Belgesi’nde de değinildiği üzere, çağdaş koruma anlayışının bir parçasıdır.

Dönem eklerine sayg1 gösterilmesi, nitelikli eklerin korunması, Violet-Le-Duc’ün mirası üslup birliği yaklaşımından uzak durulması gerekir. Dönem eklerine sayg1 göstermek, mimari mirasın farklı biçimlerde kullanılarak günümüze ulaşmasını sağlayan geçmiş dönem yapıcılarına saygının da önemli bir ifadesidir.

Çağdaş eklentilere ilişkin mimari ve tesisat projelerindeki tüm öneri ve uygulamalarda yapının özgünlügüne zarar vermeyecek ya da en az zarar verecek yöntemin belirlenmesi gerekir. Burada ilk ilke önerisi olan korumanın daimi önceliği hatırlanmalıdır. Zira aynı yapıya daha sonra farklı işlevler 
verilmesi gerektiğinde yapının önceki işlevleri ile ilgili yapılmış müdahalelerin izleri, yapı bünyesinde yeni müdahaleler gerektiren ve yapının özgün dokusunu bozan hasarlar olarak ortaya çıkacaktır.

\section{Etiğe uygunluk (Compliance with ethics)}

Etik konusunun kapsamı çok geniş olduğundan farklı biçimlerde koruma süreçleriyle ilişkilendirilmesi mümkündür. Koruma süreçlerinde yer alan uzmanlar ile ilgili etik yaklaşımın ana hatlarının 2014 yılında Floransa'da toplanan ICOMOS'un 18. Genel Kurulu'nda ortaya konduğu görülmektedir (ICOMOS Etik Illkeleri). ICOMOS üyeleri için bağlayıcı olduğu ifade edilen bu belge, üyelerin kültürel mirasa, kamuya ve toplumsal gruplara, uygulama süreçlerine yaklaşımında etik ilkeler belirlemektedir. Her ne kadar kapsamı sadece ICOMOS üyeleri ile sınırlı tutulmuş olsa da ICOMOS Etik İlkeleri'nin koruma alanında çalışan tüm uzmanlar için üst ölçekte bir belge olarak kabul edilebilecek niteliklere sahip olduğu görülür. Bununla birlikte yine de özellikle Türkiye koşulları dikkate alınarak önemli ayrıntılar olarak kabul edilebilecek bazı hususları vurgulamak faydalı olacaktır.

Projelerin hem hazırlık hem de uygulama aşamalarında, eğitim ve donanım bakımından yeterli kimselere ihale edilmesi, yeterliliğe sahip kimseler tarafindan değerlendirilerek uygulamaya geçirilmesi gerekir. Ülkemizin şartları göz önüne alındığında kültür mirasımızın onarımından sorumlu kurumların kontrol mimarlarının, koruma kurulu üye ve raportörlerinin yeterliliği ile ilgili sorunların bulunduğu görülmektedir. Kanun ve yönetmeliklerde bununla ilgili açık bir zorlayıcı hükmün bulunmaması da dikkat çekicidir (Önge, 2018, s.299). Bu bağlamda mevzuatı hazırlayanların ve düzenleyenlerin de sorumlu davranmaları gerekmektedir.

Projedeki tüm tespit ve araştırma süreçlerinin doğru ve eksiksiz bilgiler içermesi, uygulama esnasında ya da proje tamamlandıktan sonra edinilen bilgilerin proje sürecine aktarılarak projede gerekli değissikliklerin yapılması da etik ile ilgili bir husustur. Bununla ilgili olarak, Kültür ve Tabiat Varlıklarını Koruma Yüksek Kurulu'nun 660 sayılı ilke kararında da bir hüküm bulunmasına rağmen uygulama aşamasında bu sürecin işletilmediği ya da işletilemediği görülmektedir. Pek çok durumda, proje yaptıran kurumlarca projenin ilgili koruma kurulu onayından geçmesinin akabinde proje süreci sona erdirilmekte, müellif proje kontrol sürecinde yer alamamaktadır. Bazı durumlarda ise proje müellifinin hakları işveren kurum tarafindan satın alınarak proje yürütülmeye çalışılmaktadır. İşleyiş ile ilgili bu durum konuyu bir etik sorunu olmanın ötesine taşımakta, koruma sürecinde ihmal ve iletişimsizlik kaynaklı kopuklukları ve başka sorunları beraberinde getirmektedir.

Koruma proje ve uygulamalarında hazırlanan belgelerin doğru bilgiler içermesi ve verilerde tahrifat yapılmaması önemli bir konu olup, yukarıda bahsi geçen ICOMOS belgesinde de yer almaktadır. Bunun ötesinde, projedeki tüm tespit, araştırma ve müdahale süreçlerinin okunabilir bir biçimde hazırlanması, uygulayıcıya ve ilgili kurumlara eksiksiz biçimde aktarılması da gereklidir. Mimarlık haricindeki disiplinlerden gelen ekip üyeleri tarafindan hazırlanmış olan raporların, nelerin yapılması veya yapılmaması gerektiğini açık bir dille ortaya koyan sonuç bölümleri olması gerekir. Mimar, bir organizatör olarak bunu talep etmelidir.

Mimar, hazırladığı projede kendi katkısını, kültür mirasını gölgede bırakacak ya da estetik algısını bozacak biçimde ön plana çıkarmaktan kaçınması, 3.8 başlı̆̆ında açılklanmaya çalışılan saygı ilkesinin gereği olmanın ötesinde, korumanın genel etiğine de uygun bir davranış biçimidir. Zeren, 
(2010) mimari mirasa eklenecek yapının tasarımında estetik alg1yı oluşturan ve gözetilmesi gereken bazı kriterlerin varlığından bahsetmekte, bu kriterleri: çevrenin etkisi, ölçeğin etkisi, zıtlık etkisi, formun etkisi, ritim etkisi ve malzemenin etkisi olarak sıralamaktadır (s.31-33). Estetik alg1yı bozma ya da gölgede bırakma eyleminin bu kriterlerin gözetilmemesiyle ilintili olduğunu düşünmek mümkündür.

\section{Mimarın sorumluluğu (Responsibility of the architect)}

Mimari mirasın korunmasına yönelik proje ve müdahale süreçleri yeni yapı oluşturma süreçlerinden belirgin biçimde farklılıklar gösterir. Mimarın bu farklı sürece adaptasyonu bir eğitim ve donanım sorunu olup, mimarın kendi sorumluluğundadır. Koruma süreçlerini anlamak ve anlamlandırmak ancak bu süreçte alınabilecek eğitim neticesinde mümkün olabilir. Koruma projelerinde çalışacak mimarın ilk ve en önemli sorumluluğu bu konuda eğitim almaktır.

Mimari mirasın korunmasına yönelik proje hazırlanması bir uzmanlık konusudur (Venedik Tüzüğü Madde 9). Mimarın koruma ile ilgili konularda çalışıp doğru sonuçlar alabilmesi için, ölçme bilgisi, yapım bilgisi, malzeme, sanat tarihi, koruma kuramı ve koruma mevzuatı konularında bilgili olmas1 gerekir. Analizlerin hazırlanmasına yönelik tespitleri yaparken, hasarları, izleri, taşıyıcı sistem elemanlarının yerlerini ve ilişkilerini okuyabilmesi gerekir. Bunları yapabilmek için iyi bir lisans eğitimi yeterli olmayacaktır.

Mesleki birikiminin ötesinde, koruma uzmanı mimar, proje ve uygulama süreçlerinde farklı disiplinlerden koruma uzmanlarını süreç içerisinde koordine etmekle de sorumludur. Bu durumun gereği olarak mimar, farklı disiplinlerden uzmanların sürece katkısı hakkında bilgi sahibi olmalı, eğitiminin bir gereği olarak, bilgi sahibi olmadığı konularda, inisiyatif kullanmaktan kaçınmalıdır.

Mimar koruma sürecindeki rolü itibariyle topluma karşı sorumludur. Daha açık bir ifadeyle, korumanın amacı kültür mirasını gelecek nesillere tüm değerleriyle birlikte koruyarak intikal ettirmek ise mimarın bu süreçte bir organizatör olarak ilk etapta paydaşlara ve paydaşların bir parçası olduğu topluma karşı sorumluluğu bulunmaktadır.

\section{SONUÇ (EVALUATION)}

Mimari mirasın korunmasına ve onarımına yönelik proje hazırlamak, yeni yapılar inşa etmekten çok daha farklı süreçleri içeren bir uzmanlık işidir. Yapıyı tanımakla başlayan koruma projesi hazırlama aşaması, toplanan tüm bilgilerin değerlendirilmesinin ardından proje önerisi ile sona ulaşır. Bilgi toplama ve toplanan bilgilerin projeye yansitılması işleri pek çok durumda uygulama sürecinde de devam eder ve bu bilgiler süreci yeni girdilerle evriltip, geliştirir.

Proje sürecinin her anlamda sağlıklı bir şekilde işletilebilmesi ise burada ilke olarak bahsedilen hususlara özen gösterilmesi gerekir. İlk ilke olan korumanın daimi önceliği, bütün bu zahmetli ve maliyetli süreçlerin neden işletildiğinin temel gerekçesini hatırlatırken, vaka bazında yaklaşım, mimari mirasın ve sorunlarının standartlaştırılmış yöntem ve yordamlarla çözülemeyeceğini ifade etmektedir. Bilimsel yaklaşım ise günümüzün koruma anlayışında bilimsel düşüncenin sürece hakimiyetini vurgular. Multidisipliner ve katılımcıllı̆ga açık yaklaşım, korumanın sadece 
korumacıların ve siyasi iktidarın yönlendiremeyeceği kadar karmaşık bir süreç olduğunun ifadesidir. Mevzuatla etkileşim, koruma süreçlerinin yapısı itibariyle tamamen mevzuata tabi olamayacağının, mevzuatın değişen anlayış ve koşullara göre güncellenebilir olması gerekliliğinin altını çizmektedir. Uygulanabilirlik, önerilen ile sahada hayata geçirilenin sebep-sonuç ilişkisinin önemine vurgu yaparken; süreklilik ve tutarlılık ise koruma projesi sürecinin, kendi aşamaları içinde birbiriyle bağlantılı olması, yeni bilgi ve bulgularla geliştirilebilir olması, bakım ile korumanın sürekliliğin sağlanabilmesi kavramlanını işaret etmektedir. Mimarın koruma projelerinin hazırlanması sürecindeki alçakgönüllü davranış biçiminin önemi ve yapının değerleri ile dönem eklerine göstermesi gereken özen, saygı ilkesinde ele alınmıştır. Önerilen ilkelerden sonuncusu ve belki de en önemlisi, mimarın bir organizatör olarak koruma projesi sürecinden sorumlu olduğunu ve en büyük sorumluluğunun da bu süreçte eğitim almak olduğunu ortaya koyan, mimarın sorumluluğu ilkesidir.

Mimari mirasın korunmasına yönelik proje hazırlayan mimarların yukarıda bahsi geçen ilkelere uymaları ve bunların gereklerini yerine getirmeleri, kültür mirasımızın gelecek nesillere intikal ettirilmesi sürecinde hayati önem taşımaktadır.

\section{REFERANSLAR (REFERENCES)}

Alsaç, Ü. (1992). Türkiye'de Restorasyon. İstanbul: İletişim Yayınları.

Arseven, C. E. (2017). Osmanlı Dönemi Mimarlık Sözlüğü, Istılâbât-ı Mimâriyye, (çev. Şeyda Alpay). İstanbul: Kaknüs Yayınları.

Asatekin, N. G. (2004). Kültür ve Doğa Varlkklarmı,, Neyi, Niçin, Nasıl Korumalyyz??. Ankara: T.C. Kültür ve Turizm Bakanllğı.

Boito, C. (2018). Korumak mı? Restore etmek mi?, (çev. A. Tümertekin). İstanbul: Janus Yayınc1lik.

Büyüksalih, G. (2012). "Kültürel Mirasin Lazer Tarama Teknikleri ile Dokümantasyonu ve 3

Boyutlu Kent Modeli Üretimi”, Kargir Yapılarda Koruma ve Onarm Semineri, 19-20 Kasım 2012, İstanbul. İstanbul: İstanbul Büyükşehir Belediyesi İmar ve Şehircilik Daire Başkanlığı KUDEB, 56-61.

Erder, C. (2007). Taribi Çevre Bilinci. Ankara: ODTÜ Mimarlık Fakültesi.

Erder, C. (1977). "Venedik Tüzüğü Tarihi Bir Anıt Gibi Korunmalıdır”, O.D.T.Ü. Mimarlı Fakültesi Dergisi, Cilt:3, Sayı:2. Ankara: O.D.T.Ü. Mimarlık Fakültesi, 167-190, 171.

Erder, C. (1972). Restorasyon, Viollet le Duc. Ankara: ODTÜ Mimarlık Fakültesi.

Feilden, B. M. \& Jokilehto, J. (1993). Management Guidelinesfor World Heritage Sites. Rome:ICCROM.

Historic England. Lidar (Light Detection and Ranging). Alındığ1 yer https://historicengland.org.uk/research/methods/airborne-remote-sensing/lidar/

ICOMOS. (1964). Venedik Türqüğ̈̈. Alındığ1 yer http://www.icomos.org.tr/Dosyalar/ICOMOSTR_tr0243603001536681730.pdf.

ICOMOS. (1990). ICOMOS Arkeolojik Mirasin Korunması ve Yönetimi Tü̊ü̈̆̈̈̈. Alındığ1 yer 
http://www.icomos.org.tr/Dosyalar/ICOMOSTR_0844861001353670083.pdf.

ICOMOS. (2013). ICOMOS Türkiye Mimari Mirası Koruma Bildirgesi. Alındığ1 yer http://www.icomos.org.tr/Dosyalar/ICOMOSTR_tr0784192001542192602.pdf.

ICOMOS. (2014). ICOMOS Etik İlkeleri. Alındığ1 yer http://www.icomos.org.tr/Dosyalar/ICOMOSTR_en0795924001536610878.pdf

Kahya, E. (1998). Geleneksel Türk Evleri Bibliyografyası. Ankara: T.C. Kültür Bakanlığ1.

Kuban, D. (2000). Taribi Çevre Korumanın Mimarlı Boyutu. YEM Yayınları, İstanbul

Kültür ve Tabiat Varlkelarmı Koruma Kanunu. Alındığı yer http://www.mevzuat.gov.tr/MevzuatMetin/1.5.2863.pdf.

López, F., Lerones, P., Llamas, J., Gómez-García-Bermejo, J., \& Zalama, E. (2018). A review of heritage building information modeling (H-BIM). Multimodal Technologies and Interaction, 2(2), 21, 1-29.

Madran, E.,Özgönül, N. (2005). Kültürel ve Doğal Değerlerin Korunması. Ankara:TMMOB Mimarlar Odasi.

Massari, G. (1977). Humidity in Monuments. Rome: University of Rome, Faculty of Architecture.

Önge, M. (2018). "Bir Anlayış ve Sistem Sorunu Olarak Türkiye'de Modern Mimarlık Mirasının Korunması", 4. Ulusal Yapı Kongresi ve Sergisi, Yapı Sektöründe Yenilikesi Yaklaşımlar. 6-8 Aralık 2018, Antalya. Ankara: TMMOB Mimarlar Odas1, 295-303.

Riegl, A. (2015). Modern Anıt Kültü, (çev.E.Ceylan). İstanbul: Daimon Yayınları.

Shaji, T., Somayaji, S. \& Mathews, M. (2000). "Ultrasonic Pulse Velocity Technique for Inspection and Evaluation of Timber", Journal of Materials in Civil Engineering .Vol: 12, Issue:2, s:0899-1561.

Sönmez, N. (1997). Osmanlı Dönemi Yapı ve Malz̨eme Terimleri Sözlü̈̆̈̈̈. İstanbul: YEM Yayın.

T.C. Anayasası. Alındığı yer https://www.tbmm.gov.tr/anayasa/anayasa_2016.pdf.

T.C. Kültür ve Turizm Bakanlığı. T.C. Kültür ve Turizm Bakanllğı Kültür ve Tabiat Varlıklarmı Koruma Yülesek Kurulu'nun 660 sayzl ilke karar. Alındığ1 yer

http://teftis.kulturturizm.gov.tr/TR,13918/660-nolu-ilke-karari-tasinmaz-kulturvarliklarinin-grup-.html.

Titman, D. J. (2001). Applications of thermography in non-destructive testing of structures. NDT \&e International, 34(2), 149-154.

Thurley, S. (2005). Into the future. Our strategy for 2005-2010. Conservation bulletin, 49(49), 26-27.

Uluengin, B. (2002). Rölöve. İstanbul: Yapı Endüstri Merkezi Yayınları

Üredi, K. (2009). Şebrin Ahşap Zamanı. İstanbul: Ötüken Neşriyat.

Vakıflar Genel Müdürlüğü. V akıflar Genel Müdürlüğ̈ Müzeler Yönetmelĭ̆i. Alındığı yer https://www.mevzuat.gov.tr/Metin.Aspx?MevzuatKod=7.5.11076\&MevzuatIliski=0\&sour ceXmlSearch $=$ Vak $\% C 4 \% B 1$ flar $\% 20$ Genel $\% 20 \mathrm{M} \% \mathrm{C} 3 \% \mathrm{BCd} \% \mathrm{C} 3 \% \mathrm{BCrl} \% \mathrm{C} 3 \% \mathrm{BC} \% \mathrm{C} 4 \% 9$ 
$\mathrm{F} \% \mathrm{C} 3 \% \mathrm{BC}$

Vinas, S. M. (2005). Contemporary Theory of Conservation. Oxford: Elsevier Ltd.

Zakar, L. \& Eyüpgiller, K. (2018). Mimari Restorasyon Koruma Teknik ve Yöntemleri. İstanbul: Ömür Matbaacilik.

Zeren, M.T. (2010). Taribi Çevrede Yeni Ek ve Yeni Yapı Olgusu. İstanbul : Yalın Yayıncılık.

\section{YAZARIN BIIYOGRAFİSİ (BIOGRAPHY OF THE AUTHOR)}

\section{Mustafa Önge}

1976 Ankara doğumlu olan Önge, ilk, orta ve lise tahsilini Konya'da yapmıştır. Gazi Üniversitesi Mimarlık Fakültesi Mimarlık Lisans programından 1998 yllında mezun olduktan sonra, 2004 yılında Orta Doğu Teknik Üniversitesi Restorasyon Yüksek Lisans Programı'nda “Konya Yakmlarnnda Bir 13.yy. Selçuklu Kervansaray Olan Zaz̧adin Han'in Restorasyonu” başlıklı tez çalışmasını tamamlayarak yüksek mimar restorasyon uzmanı ünvanını almıştır. Yüksek lisans sonrasında eğitimine Orta Doğu Teknik Üniversitesi Restorasyon Doktora Programı’nda devam etmiş, hazırladığ1 "19. Yǚsylldan Günümüze Konya Alaeddin Tepesi’ndeki Kültürel Varlıklarn Korunması” konulu doktora tezi çalışmasını 2011 yılında tamamlamıştır. 2012 yllında, doktora tezi çalışmasıyla ODTÜ Lisansüstü Tez Ödülü’ne layık görülmüştür. 2002 y1lından başlayarak Çankaya Üniversitesi’nde sürdürdügü akademik görevlerinin yanısıra, 2013-2018 yılları arasında Sivas Kültür Varlıklarını Koruma Bölge Kurulu üyeliği görevinde de bulunmuştur. Halen Çankaya Üniversitesi Mimarlık Fakültesi Mimarlık Bölümü’nde Dr. Öğr. Üyesi olarak görev yapmaktadır. Akademik ilgi alanları arasında koruma tarihi, koruma mevzuatı, tarihi yapılarda yapım teknikleri ve malzeme konuları yer almaktadır. Ulusal ve uluslararası alanda yayınları olan Önge, evli ve iki çocuk babasıdır. 